\title{
Ultrastructure of the frontal gland in Prorhinotermes simplex (Isoptera: Rhinotermitidae) and quantity of the defensive substance
}

\author{
Jan ŠOBOTNÍK ${ }^{1, *}$, FrantišeK WEYDA ${ }^{2}$, Robert HANUS ${ }^{1}$, PaVlína KYJAKOVÁ ${ }^{1}$ JAN DOUBSKÝ ${ }^{1}$ \\ ${ }^{1}$ Institute of Organic Chemistry and Biochemistry, Flemingovo nám. 2, Praha 6, CZ - 166 10, Czech Republic; \\ e-mail: sobotnik@uochb.cas.cz \\ ${ }^{2}$ Institute of Entomology, Branišovská 31, České Budějovice, CZ - 370 05, Czech Republic
}

\begin{abstract}
Key words. Ultrastructure, frontal gland, termite, Isoptera, Rhinotermitidae, Prorhinotermes simplex, Prorhinotermes inopinatus, intercaste, defence secretion, $E$-1-nitropentadecene
\end{abstract}

\begin{abstract}
The frontal gland as a sac-like organ in Prorhinotermes simplex is present only in presoldiers, soldiers, and imagoes, but exists also in nymph-soldier intercastes. The secretory epithelium consists of a single type of secretory cells adhering directly to the cuticular intima. Secretory vacuoles originate in electron dense vesicles, which are transformed into large electron lucent vacuoles. Intermediate vacuoles frequently contain lipid droplets. The frontal gland cells in presoldiers reveal modifications connected with the production of a new cuticle; the new cuticle is thin and compact, whereas the old one is thick, porous, and wrinkled. None of these cuticles is present in soldiers (sic!). In soldiers, the cuticular intima is of endocuticular origin and is formed by dispersed dense material; the apical parts of secretory cells are formed by numerous irregular finger-like projections, true microvilli are completely lacking. In imagoes, the cuticle is composed of an epicuticle, a layer of epicuticular filaments, and one more basal layer; sexual differences were not observed. In nymph-soldier intercastes, the structure of the gland differs in the head and in the metathorax; the head part of the gland resembles the imaginal gland whereas the thoracic part resembles more that of the soldier; the development of secretory vacuoles stops at the stage of presence of lipid droplets. $E$-1-nitropentadecene was found in the highest amount in soldiers (comparable to P. inopinatus soldiers), in moderate amount in imagoes, and it is missing in both presoldiers and intercastes.
\end{abstract}

\section{INTRODUCTION}

The isopteran frontal gland is among the most powerful defensive weapons in the animal kingdom. According to Clément et al. (1988), the frontal gland reservoir of Reticulitermes spp. (Isoptera: Rhinotermitidae) soldiers contains secretion sufficient to kill up to several hundred ant intruders. The produced chemicals have diverse defensive functions sensu lato. Particular substances are toxic, repellent, or sticky; they may act as alarm pheromones or may even influence soldier differentiation (Renoux, 1976; Lefeuve \& Bordereau, 1984; Prestwich, 1984; Roisin et al., 1990). Soldiers of Rhinotermitidae produce contact poisons (Prestwich, 1984). The emergence of these poisons led to the evolution of biochemical mechanisms preventing autotoxication, as was shown in Schedorhinotermes lamanianus (Sjöstedt, 1911) (Isoptera: Rhinotermitidae) and Prorhinotermes simplex (Hagen, 1858) by Spanton \& Prestwich (1981). Soldiers of P. simplex and P. flavus (Bugnion \& Popoff, 1910) produce predominantly $E$-1-nitropentadec-1-ene (Vrkoč \& Ubik, 1974; Chuah et al., 1990), the only nitrocompound produced by insects (Deligne et al., 1981).

The frontal gland is an organ with no equivalent in other insects (Noirot, 1969). It is present only in representatives of termite families: Rhinotermitidae, Serritermitidae, and Termitidae (Noirot, 1969; Costa-Leonardo \& Kitayama, 1991; Costa-Leonardo, 1998). The gland is always a sac-like organ that opens through the frontal pore (fontanelle). The fontanelle is sometimes missing, and then the gland is reduced (as in some Macrotermitinae and Termitinae; Deligne et al., 1981) or fully developed, as in Serritermes serrifer (Hagen \& Bates, 1858) (Isoptera: Serritermitidae) (see Costa-Leonardo \& Kitayama, 1991; Costa-Leonardo, 1998) and Globitermes sulphureus (Haviland, 1898) (Isoptera: Termitidae) (see Bordereau et al., 1997). A well developed gland is present in soldiers and sometimes in imagoes, and it was also described in presoldiers of P. simplex (see Šobotník \& Hubert, 2003) and Globitermes sulphureus (see Bordereau et al., 1997) although it probably exists in presoldiers of other species, too. Ultrastructural features of the frontal glands are known in soldiers of several species, but neither an ultrastructural study of the frontal gland in presoldiers, imagoes, and intercastes nor a precise amongcaste comparison have yet been published.

Morphogenetic effects of juvenile hormone analogues (JHA) application, resulting in soldier intercastes formation, have been demonstrated many times (for review see Su \& Scheffrahn, 1990). Nevertheless, precised morphological and anatomical data on intercastes are scarce (e.g., Springhetti \& Rossi, 1983; Myles \& Chang, 1984; Lelis \& Everaerts, 1993).

The aim of this study is to describe the frontal gland in all castes of $P$. simplex in which it occurs, and to compare its structure in natural individuals and in nymph-soldier intercastes induced by JHA; the major question is whether the structure of the gland in the latter is closer to the situation observed in imagoes or to that in soldiers.

\footnotetext{
* Corresponding author.
} 
We have compared the amount of the defensive compound $E$-1-nitropentadecene in the studied castes and tried to highlight the relationships between the quantity of $E$-1-nitropentadecene produced, the size of the gland reservoir, and the structure of secretory cells.

\section{MATERIAL AND METHODS}

\section{Termites}

The material of Prorhinotermes inopinatus (Silvestri, 1909) originates from a colony collected by Lukáš Čížek in the Kau Wildlife Area (lat. S 508'; long. E $145^{\circ} 46^{\prime} ; 50 \mathrm{~m}$ a.s.1.) adjacent to the Baitabag village near Madang (Madang Province, Papua New Guinea) on February $5^{\text {th }}, 2000$, and kept in the laboratory at $26 \pm 1{ }^{\circ} \mathrm{C}$ since then.

All individuals of Prorhinotermes simplex (Hagen, 1858) originated from a colony collected by Jan Křeček in Soroa (Pinar del Rio, Cuba) on December $14^{\text {th }}, 1964$, and kept in the laboratory at $26 \pm 1{ }^{\circ} \mathrm{C}$ since then.

\section{Intercastes production}

Intercastes were obtained by the following treatment. Groups of 50 nymphs were kept in $60 \mathrm{~mm}$ diameter Petri dishes on moistened substrate $(6 \mathrm{ml}$ of $1: 1$ mixture of fine sand and vermiculite) under constant temperature of $26^{\circ} \mathrm{C}\left( \pm 1^{\circ}\right)$. Spruce wood blocks $(30 \times 10 \times 2 \mathrm{~mm})$ were offered to the termites as the only source of food. These blocks were impregnated with $500 \mathrm{ppm}$ (wt : vol) acetone solution of JHA W-328 (for structure and synthesis see Wimmer et al., 1997). White nymph-soldier intercastes were removed and placed in groups of pseudergates feeding on non-treated wood until they moulted into nymph-soldier intercastes.

\section{Optical and transmission electron microscopy}

The structure of frontal glands was examined in the head of all castes, in the metathorax of presoldiers, soldiers, and intercastes, and in the middle part of the abdomen of soldiers. Whole body parts (heads, thoraxes, abdomens) were fixed in a mixture of $2 \%$ glutaraldehyde and $2.5 \%$ formaldehyde (Polysciences, EM Grade) in $0.1 \mathrm{M}$ phosphate buffer for 1 to 3 days (at room temperature). After washing in pure $0.1 \mathrm{M}$ phosphate buffer, tissues were postfixed in $2 \%$ osmium tetroxide (also in $0.1 \mathrm{M}$ phosphate buffer) for 2 hours. Then the samples were washed in bidistilled water and dehydrated in $50 \%, 75 \%$, and absolute ethanol. Later, they were embedded in Spurr resin (standard mixture). Semithin and ultrathin sections were made with a Reichert Ultracut ultramicrotome. Semithin sections were stained by methylene blue and studied in an Axioskop Weiss optical microscope (with Sony Cyber-shot digital camera). Ultrathin sections were stained with uranyl acetate and lead citrate (standard recipe), and they were studied in a Jeol 1010 transmission electron microscope.

\section{Measurement of the quantity of $\boldsymbol{E}$-1-nitropentadecene}

Gas chromatography-mass spectrometry was performed on a Carlo Erba GC 8000 series gas chromatograph and Fisons MD 800 mass detector (quadrupole mass spectrometer using $70 \mathrm{eV}$ electron impact ionization). Chromatography was carried out on a DB-5ms nonpolar fused silica capillary column (5\% phenyl-95\% methyl siloxane phase, $30 \mathrm{~m} \times 0.25 \mathrm{~mm}$, film thickness $0.25 \mu \mathrm{m}$, JandW Scientific). The split/splitless injector was operated in a splitless mode at $200^{\circ} \mathrm{C}$, the split vent was opened after $60 \mathrm{sec}$. Helium was used as a carrier gas at 1 $\mathrm{mL} / \mathrm{min}$ (measured at $50^{\circ} \mathrm{C}$ ). The oven temperature program was $50^{\circ} \mathrm{C}$ for $2 \mathrm{~min}$, then $10^{\circ} \mathrm{C} / \mathrm{min}$ to $300^{\circ} \mathrm{C}$, and held for 20 min. For the measurement of the quantity of $E$-1-nitropentadecene all castes of $P$. simplex were used, in which a sac- like frontal gland is developed (presoldiers, soldiers, imagoes of both sexes), nymph-soldier intercastes of $P$. simplex, and soldiers of $P$. inopinatus. Five individuals of each category were macerated in $20 \mathrm{ml}$ hexane for 36 hours. Each sample was run three times on GC-MS. To each sample, $0.5 \mathrm{mg}$ of synthetic standard was added for quantification and was run again three times. From those data, the quantity of $E$-1-nitropentadecene per animal was calculated. For a method of $E$-1-nitropentadecene synthesis see Kuldová et al. (1999).

\section{RESULTS}

\section{Common features}

The frontal gland is always a simple sac-like organ differing among particular castes in its size and shape (Fig. 1). The frontal gland epithelium consists in all castes of a single type of secretory cells (class 1 cells according to Noirot \& Quennedey, 1974), which are connected by apical desmosomes followed by a long septate junction. The secretory cells include a dense network of microtubules that are attached either to the desomome or to hemidesmosomes adhering to the basement membrane. The basal parts of the membranes are free.

Many class 3 secretory cells (according to Noirot \& Quennedey, 1974) emit their products into the canal connecting the fontanelle and the gland. Their structure is the same as in other bicellular dermal glands in the head and very similar among particular castes. The cytoplasm of the class 3 secretory cells contains rough endoplasmic reticulum (RER), numerous Golgi apparatuses, and many mitochondria. Their vacuoles are of two types. Electron lucent vacuoles are released from the Golgi apparatuses while the electron dense ones are probably produced by RER. Both types may empty into an extracellular reservoir. The fewest vacuoles occur in presoldiers; other aspects are the same in all castes. The class 3 secretory cells associated with the frontal gland differ neither among the particular castes nor between the frontal gland canal and other body parts. We assume that the function of their products is generally protective.

Table 1 shows an overview of selected features of frontal gland development in the studied castes and nymph-soldier intercastes. Development of secretory vacuoles in soldiers, imagoes and nymph-soldier intercastes is summarized in Fig. 5.

\section{Presoldier}

Fig. 2 is a schematic drawing of a secretory cell of a presoldier. In the gland reservoir of all individuals, there occurs an old cuticle. It is always wrinkled in the gland lumen, and separated from the secretory epithelium. It is about $1.5 \mu \mathrm{m}$ thick, porous, and formed by four layers (Fig. 8). New cuticle is produced by the secretory epithelium in late presoldiers. It is formed by an outer epicuticle, about $30 \mathrm{~nm}$ thick (Fig. 6), which consists of three layers. The outer and inner layers are dense and the intermediate layer is lucent.

Cell borders are formed by slightly folded membranes. Membranes of neighbouring cells reveal no connection from approximately half of the epithelium thickness. Shallow basal invaginations occur only infrequently (Fig. 

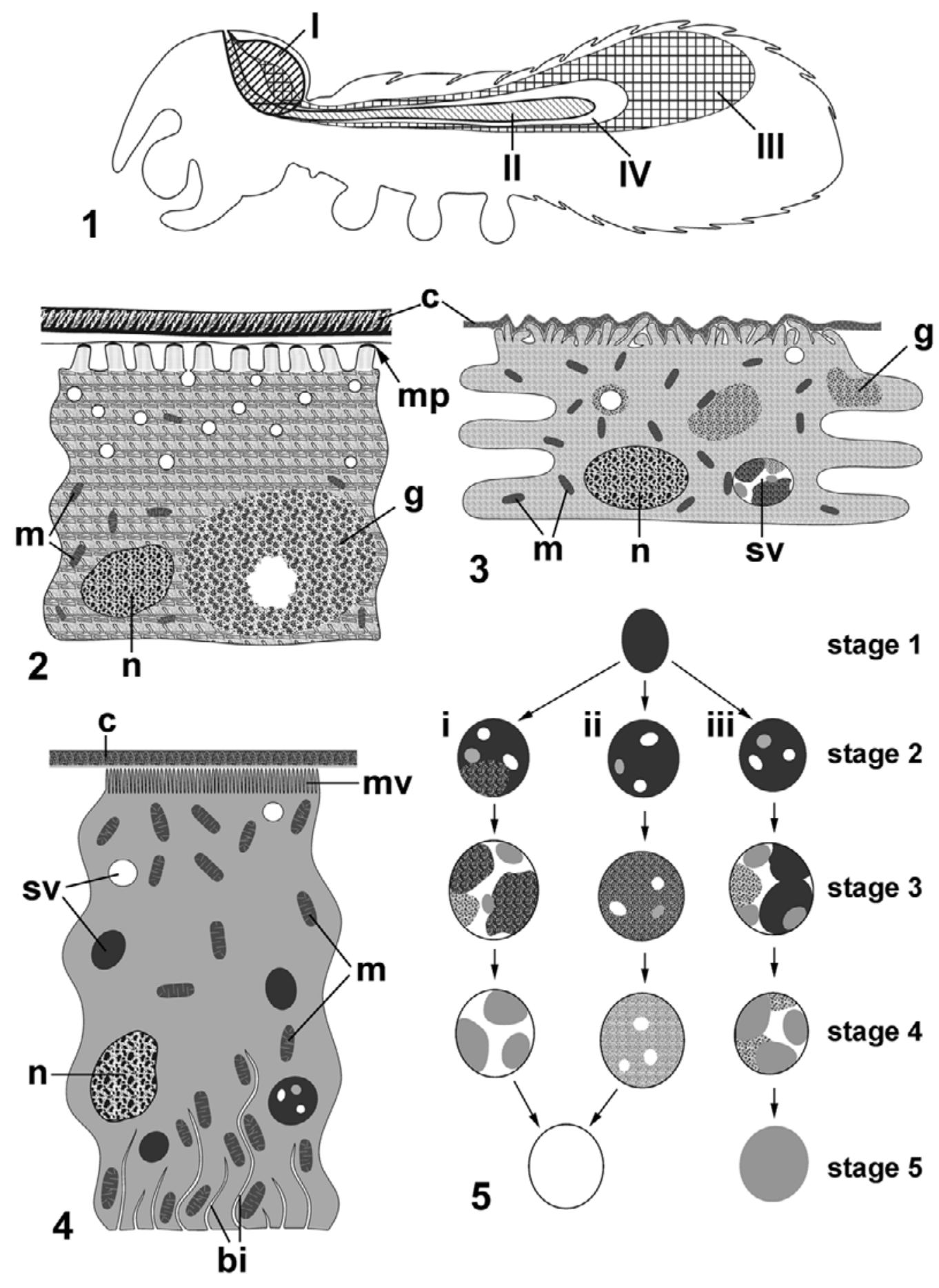

Figs 1-5: Prorhinotermes simplex (schematic illustrations of the position and size of the frontal gland, of the frontal gland cell and of the development of secretory vacuoles). 1 - position and size of the frontal gland in (I) imago, (II) presoldier, (III) soldier and (IV) nymph-soldier intercaste; 2 - frontal gland cell in presoldier; 3 - frontal gland cell in soldier; 4 - frontal gland cell in alate imago; 5 - development of secretory vacuoles in (i) soldier, (ii) imago and (iii) nymph-soldier intercaste. Lettering: bi - basal invagination; $\mathrm{c}$ - cuticle; $\mathrm{g}$ - glycogen; $\mathrm{m}$ - mitochondria; $\mathrm{mp}$ - epidermal moulting plaque; $\mathrm{mv}$ - microvilli; $\mathrm{n}$ - nucleus; $\mathrm{sv}$ - secretory vacuole.

7). The cytoplasm contains numerous cisternae of RER and free ribosomes (Fig. 6). Golgi apparatuses occur in low numbers. Glycogen is present in considerable amounts, predominantly in the basal regions. Gaps (2 to 3 $\mu \mathrm{m}$ in diameter) occur in the centre of these glycogen accumulations (Fig. 7). Two types of vacuoles were observed in the apical parts of the secretory cells. Smaller vacuoles (about $150 \mathrm{~nm}$ ) are more numerous; they are 
TABLE 1. Summarization of selected characteristics of frontal gland development in studied castes and nymph-soldier intercaste in Prorhinotermes simplex.

\begin{tabular}{|c|c|c|c|c|}
\hline & Presoldier & Soldier & Imago & Intercaste \\
\hline $\begin{array}{l}\text { Shape and extend of the } \\
\text { gland (see also Fig. 1) }\end{array}$ & $\begin{array}{l}\text { simple tube } \\
\text { reaching to the III. } \\
\text { abdominal segment }\end{array}$ & $\begin{array}{l}\text { widened in head, } \\
\text { narrowed in cervix, } \\
\text { slowly broadened untill } \\
\text { its end in the VII. } \\
\text { abdominal segment }\end{array}$ & $\begin{array}{l}\text { posterodorsal part of } \\
\text { the head (see Fig. 16) }\end{array}$ & $\begin{array}{l}\text { wide in head, narrow in } \\
\text { cervix, slowly expands } \\
\text { untill its end in the } \\
\text { anterior part of the } \\
\text { abdomen }\end{array}$ \\
\hline $\begin{array}{l}\text { Thickness of the secretory } \\
\text { epithelium (in } \mu \mathrm{m} \text { ) }\end{array}$ & $10-15$ & $4-10$ & $\begin{array}{l}\text { dorsal part usually } \\
\text { thinner }(1.5-5) \text {, than } \\
\text { ventral part }(8-30)\end{array}$ & $\begin{array}{c}8-30 \text { in head; } 2-6 \text { in } \\
\text { metathorax }\end{array}$ \\
\hline $\begin{array}{l}\text { Composition and thickness } \\
\text { (in } \mu \mathrm{m}) \text { of the cuticle }\end{array}$ & $\begin{array}{l}\text { old cuticle in the } \\
\text { reservoir }(1500) \text {; } \\
\text { new cuticle in late } \\
\text { presoldier consists } \\
\text { of outer epicuticle } \\
\text { (30) only }\end{array}$ & $\begin{array}{c}\text { modified porous } \\
\text { endocuticle }(150-300) \\
\text { only close to fontanelle } \\
\text { consists of outer }(35) \text { and } \\
\text { inner }(45-65) \text { epicuticle } \\
\text { and endocuticle } \\
\quad(200-350)\end{array}$ & $\begin{array}{l}\text { outer epicuticle (30), } \\
\text { inner epicuticle ( } 70) \text {, } \\
\text { layer of epicuticular } \\
\text { filaments (400-1100), } \\
\text { basal layer (100) }\end{array}$ & $\begin{array}{l}\text { present only in head } \\
\text { part; epicuticle (60), } \\
\text { layer of epicuticular } \\
\text { filaments }(100-400)\end{array}$ \\
\hline $\begin{array}{l}\text { Density and length } \\
\text { (in } \mu \mathrm{m}) \text { of microvilli }\end{array}$ & $\begin{array}{l}\text { scarce and short, } \\
\text { bearing typical } \\
\text { moulting plaques }\end{array}$ & true microvilli are lacking & $\begin{array}{l}\text { dense and long } \\
(1.3-2.2) \text {; containing } \\
\text { actin-like filaments }\end{array}$ & $\begin{array}{c}\text { dense and short } \\
(0.5-0.8) \text { in head; } \\
\text { spaced and shorter } \\
(0.3-0.5) \text { in metathorax }\end{array}$ \\
\hline $\begin{array}{l}\text { Shape and size (in } \mu \mathrm{m}) \text { of } \\
\text { nuclei }\end{array}$ & $\begin{array}{l}\text { highly irregular; } \\
\text { 5-8.5 }\end{array}$ & regular, round or ovoid; 6 & highly irregular; 6-7 & slightly irregular; 5-7 \\
\hline $\begin{array}{l}\text { Abundance and size } \\
\text { (in } \mu \mathrm{m}) \text { of mitochondria }\end{array}$ & $\begin{array}{c}\text { moderately } \\
\text { abundant; usually } \\
<0.5\end{array}$ & $\begin{array}{c}\text { abundant, usually about } \\
0.5 \text {, infrequently } \\
\text { up to } 2\end{array}$ & $\begin{array}{l}\text { very populous; } \\
\text { usually } 0.5 \mu \mathrm{m} \text {; often } \\
\text { up to } 2 \mu \mathrm{m}\end{array}$ & $\begin{array}{c}\text { abundant but small } \\
(0.2-0.4, \text { rarely up to } 1)\end{array}$ \\
\hline $\begin{array}{l}\text { Composition and thickness } \\
\text { of the basement membrane } \\
\text { (in } \mu \mathrm{m} \text { ) }\end{array}$ & thin; about 70 & $\begin{array}{l}\text { thin; about } 80 \text {; in head } \\
\text { may contain collagen } \\
\text { fibres, then } 150-200\end{array}$ & $\begin{array}{l}\text { very thin; about } 35 \text {; } \\
\text { when containing } \\
\text { collagen fibres } \\
50-120\end{array}$ & thin; about 70 \\
\hline
\end{tabular}

electron lucent but with dense margins. They serve probably only for the production of new cuticle. Larger vacuoles $(0.3$ to $1.2 \mu \mathrm{m})$ are rare and contain various proportions of electron lucent and dense material. We expect that the larger vacuoles contain precursors of defensive substances.

\section{Soldier}

Fig. 3 is a schematic drawing of a secretory cell of a soldier. The cuticle overlaying the secretory epithelium is of unusual appearance: it is thin (150 to $300 \mathrm{~nm})$ and porous (Fig. 14). Unmodified body cuticle changes into this unusual structure along the canal connecting the reservoir with the outside. The cuticle close to the fontanelle is formed by outer and inner epicuticle and endocuticle. The outer epicuticle, about $35 \mathrm{~nm}$ thick, is formed by three equally thick sublayers. The inner and outer sublayers are electron dense while the intermediate layer is electron lucent. The thickness of the electron dense inner epicuticle ranges between 45 and $65 \mathrm{~nm}$. The endocuticle is formed by several poorly defined sublayers and its thickness varies between 200 and $350 \mathrm{~nm}$. Deeper in the canal, the inner epicuticle becomes fragmented, and the endocuticle looses its layered pattern and becomes more electron dense and irregularly porous (Fig. 15). Further, the epicuticle disappears and the endocuticle takes the dense and porous form which is typical of the cuticle in the rest of the gland.
Intercellular membranes are strongly folded (Figs 13, 15). Basal invaginations are developed only locally in the head but are relatively deep. Numerous mitochondria are connected to these invaginations. Muscles are attached to the basement membrane containing collagen fibres by a series of hemidesmosomes. The apical plasma membrane forms irregular finger-like projections (Fig. 14).

Glycogen rosettes are located predominantly in the basal parts and they often surround secretory vacuoles. The formation of secretory vacuoles takes place in the basal regions of the cells (Fig. 9). The sequence of development of secretory vacuoles begins in electron dense granules about $1 \mu \mathrm{m}$ in diameter (stage 1) (Figs 5, 12, 15), which are probably of mitochondrial origin. These dense granules increase in size concurrently with the appearance of electron lucent parts and the fragmenting of dense parts (stage 2) (Figs 11, 12). Myelin figures may rarely occur inside the dense granules and replace them (Fig. 12). Vacuoles in an intermediate stage (stage 3) are very large (up to $5 \mu \mathrm{m}$ ) and contain electron dense flocculent coagulations, electron lucent parts, and often also fragmented glycogen particles (Figs 9, 10). Vacuoles in stage 3 are frequently associated with mitochondria. During stages 2 and 3, lipid droplets appear inside the vacuoles (Fig. 10). Dense coagulations disappear and the vacuoles become filled predominantly by lipids (stage 4) (Fig. 11). Finally, lipids dissolve and the vacuole becomes electron lucent (stage 5) (Fig. 13). Vacuoles in 


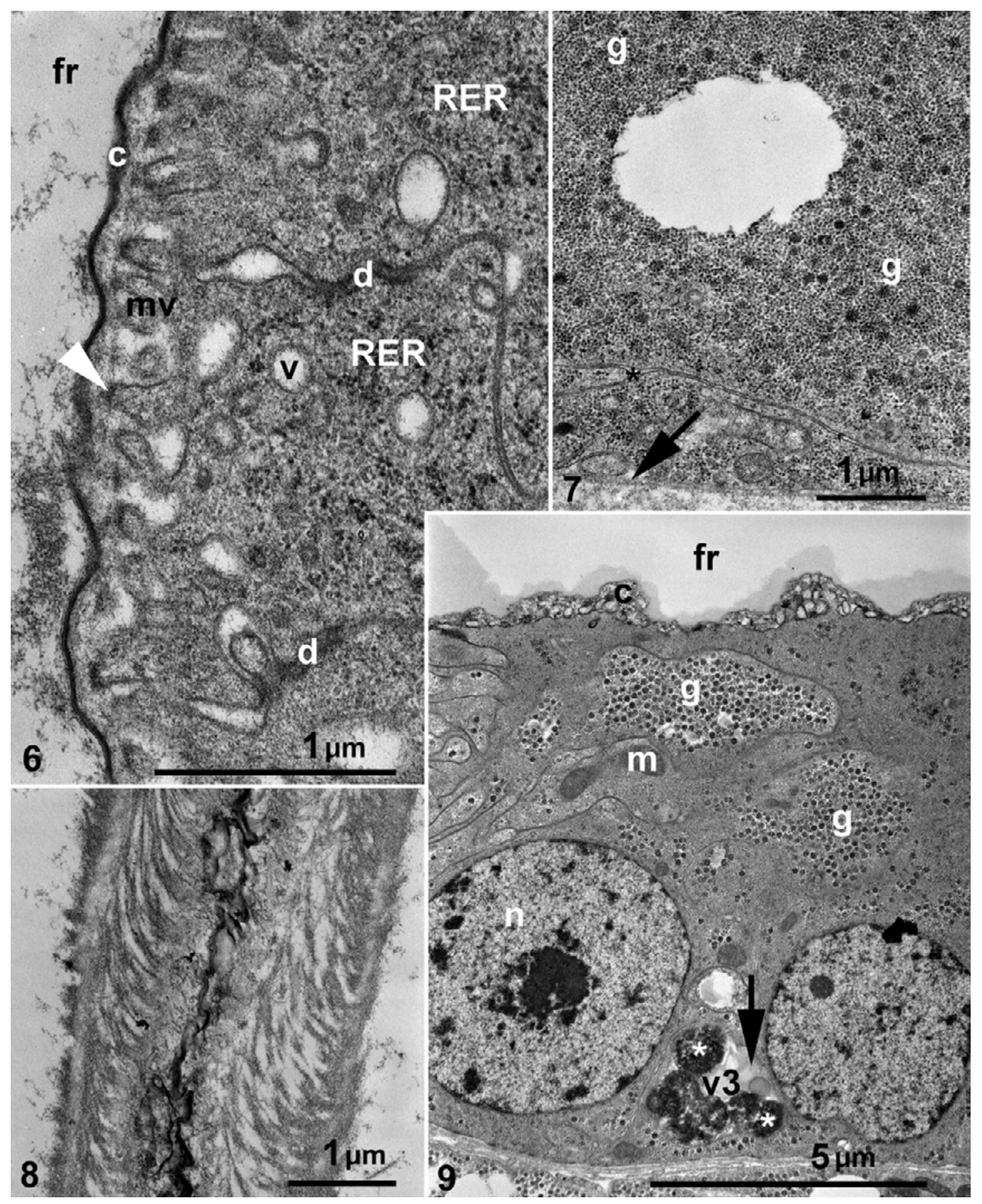

Figs 6-9: Prorhinotermes simplex (frontal gland secretory cells in presoldier and soldier). 6 - apical part of the secretory epithelium in presoldier. Note the newly produced cuticle. Arrowhead marks epidermal moulting plaque; 7 - basal part of a secretory cell in presoldier. Note the large accumulation of glycogen rosettes. Asterisk marks basal invagination, arrow marks basement membrane; 8 - detailed view on the facing parts of the old cuticle wrinkled in the frontal gland reservoir in presoldier; 9 - secretory epithelium in the metathorax of a soldier. Note the lipid droplet inside the secretory vacuole. Arrow marks the basement membrane, arrowhead marks lipid droplet, asterisks mark electron dense coagulations. Lettering: $\mathrm{c}$ - cuticle; $\mathrm{d}$ - desmosome; fr - frontal gland reservoir; $\mathrm{g}$ - glycogen; $\mathrm{m}$ - mitochondria; $\mathrm{mv}$ - microvilli; $\mathrm{n}$ - nucleus; RER - rough endoplasmic reticulum; $\mathrm{v}$ - vacuole; $\mathrm{v}$ secretory vacuole of stage 3 .

the final stages of their development may fuse with the apical membrane. These are usually electron lucent, sometimes with remnants of lipids. Release of vacuoles filled with dense coagulation was rarely observed. Vacuoles in stages 4 and 5 are usually surrounded by numerous glycogen rosettes (Figs 11, 13). The whole process of formation of secretory products was observed only infrequently in soldiers; vacuoles were found mostly in stage 3 . 

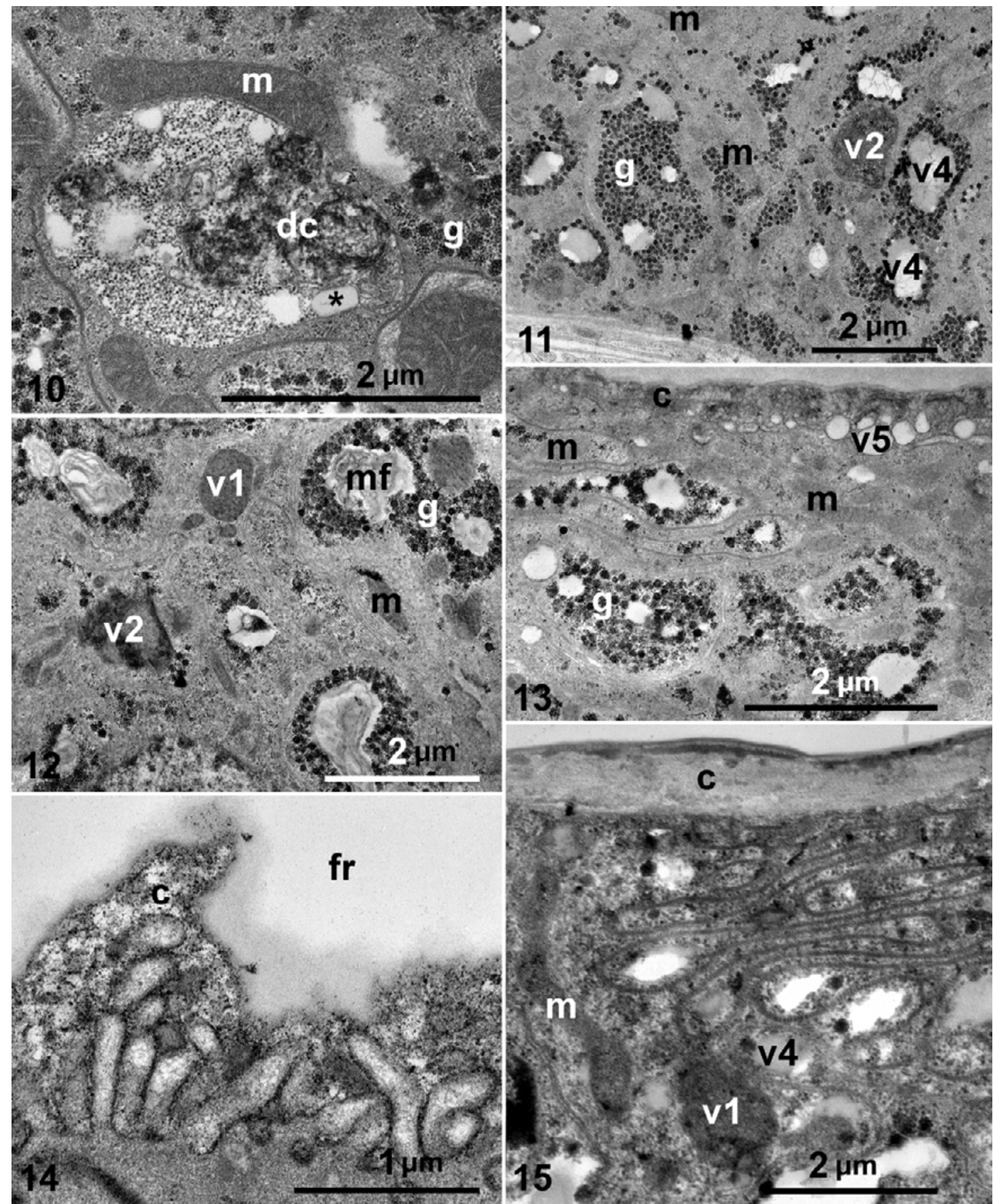

Figs 10-15: Prorhinotermes simplex (ultrastructure of the soldier frontal gland cells). 10 - detail of secretory vacuole in the stage characteristic for soldiers (stage 3). Note the close association of mitochondrion with the vacuole and glycogen particles inside the vacuole. Asterisk marks lipid droplet; 11 - secretory cell in the metathorax. Vacuoles are surrounded by glycogen rosettes and include lipids; 12 - secretory granules decomposing into myelin figures in the metathorax; 13 - excluding of vacuoles filled with the definite secretion in the abdomen; 14 - apical part of the secretory epithelium in the abdomen. Note the irregular finger-like projections of the plasma membrane and the diffuse structure of the cuticle; 15 - apical part of the secretory epithelium forming a canal connecting the reservoir and the fontanelle. Note the cuticle formed by an outer epicuticle, an inner epicuticle (fragmented electron dense layer), and an endocuticle. Lettering: $\mathrm{c}$ - cuticle; $\mathrm{dc}$ - electron dense coagulation; $\mathrm{fr}$ - frontal gland reservoir; $\mathrm{g}-\mathrm{glycogen} ; \mathrm{m}$ - mitochondria; $\mathrm{mf}$ - myelin figure; v1-v5 - secretory vacuoles of stages 1 to 5 .

\section{Imagoes}

Fig. 4 is a schematic drawing of a secretory cell of an imago. Gland cuticle is composed of several layers (Fig. 18 ); its total thickness is about $1 \mu \mathrm{m}$. There is a basal layer about $100 \mathrm{~nm}$ thick that is electron lucent in some places but electron dense in others. The thickness of the layer of epicuticular filaments varies from 0.4 to $1.1 \mu \mathrm{m}$. Small electron lucent vacuoles (100 to $200 \mathrm{~nm}$ in diameter) are commonly present within the layer of epicuticular filaments. The inner epicuticle is moderately dense and 


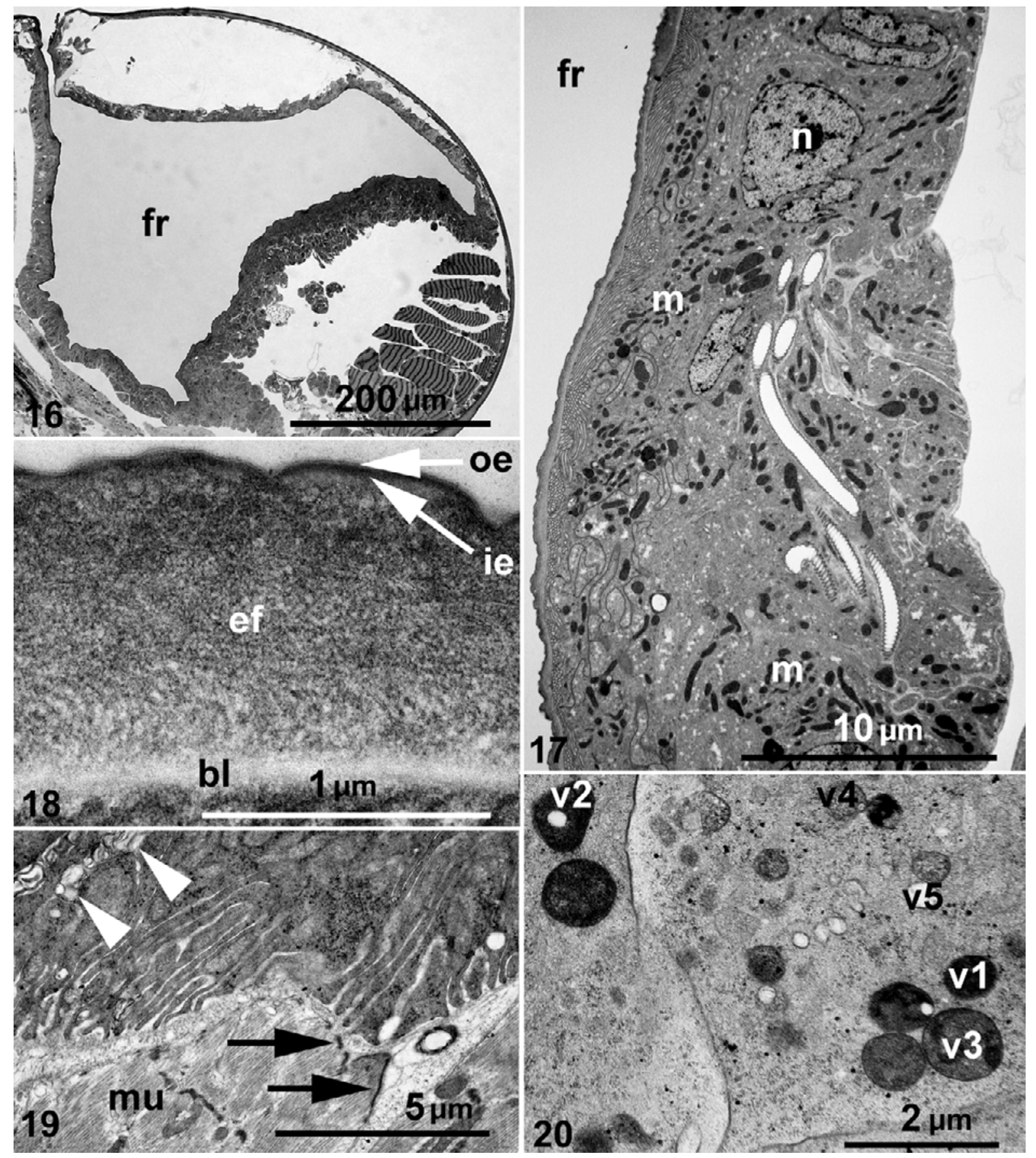

Figs 16-20: Prorhinotermes simplex (ultrastructure of the imago frontal gland cell). 16 - sagital section of head of a male; 17 anterior part of secretory epithelium in a female. Note the tracheae in the basal part of the secretory epithelium; $18-$ detail of the cuticular intima of the frontal gland in a female; 19 - basal part of the secretory epithelium in a female showing a muscle attachment. Arrows mark hemidesmosomes, arrowheads indicate myelin figures located inside the basal invaginations; 20 - cross section through the apical part of the secretory epithelium in a female. Arrowhead marks a lipid droplet. Lettering: bl - basal layer of cuticle; ef - layer of epicuticular filaments; fr - frontal gland reservoir; ie - inner epicuticle; $\mathrm{m}$ - mitochondria; mu - muscle; $\mathrm{n}$ nucleus; oe - outer epicuticle; v1-v5 - secretory vacuoles of stages 1 to 5.

about $70 \mathrm{~nm}$ thick. The outer epicuticle (about $30 \mathrm{~nm}$ thick) is comprised of three sublayers. The medial sublayer is electron lucent while the inner and outer sublayers are dense.

Cell borders are sinuate (Fig. 17). Basal invaginations are always deep (they may attain half of the epithelium thickness) (Figs 17, 19) and are present in all parts of the gland. Numerous mitochondria are associated with the basal invaginations. Myelin figures were infrequently observed inside the basal invaginations (Fig. 19). Tracheae are located close to the basement membrane but commonly penetrate it and are situated among the secretory cells (Fig. 17). Muscles are attached to the basement membrane by series of hemidesmosomes (Fig. 19). Col- 


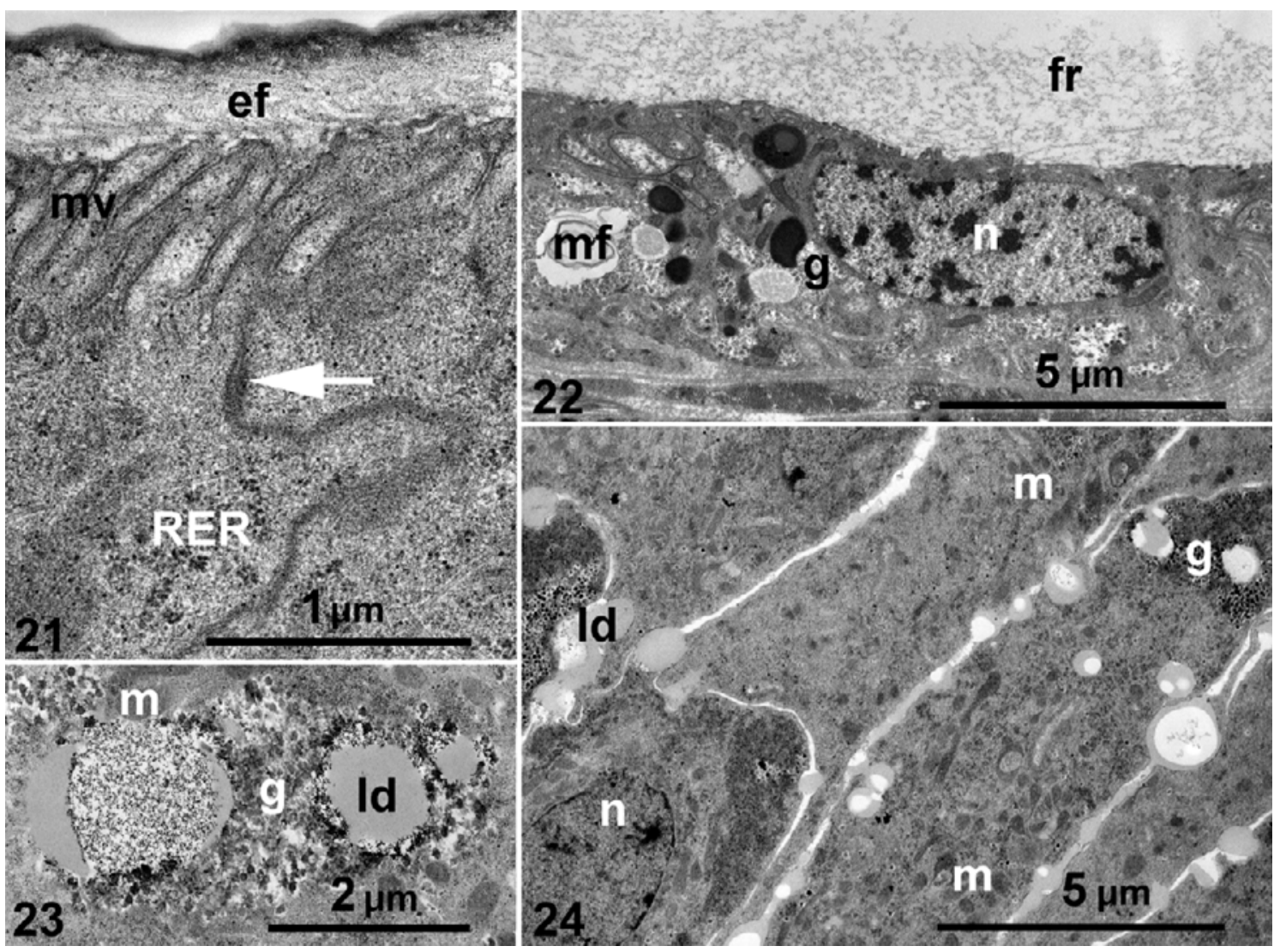

Figs 21-24: Prorhinotermes simplex (ultrastructure of the nymph-soldier intercaste frontal gland cells). 21 - apical part of the secretory epithelium in the head. Arrow marks a desmosome; 22 - secretory cells of the frontal gland in the metathorax. Note various stages of secretory vacuoles development; 23 - detail of the development of the secretory vacuole stage 3 in the head part of the frontal gland; 24 - head part of the frontal gland showing lipid droplets accumulated within intercellular spaces. Lettering: ef layer of epicuticular filaments; fr - frontal gland reservoir; $\mathrm{g}$ - glycogen; ld - lipid droplet; $\mathrm{m}$ - mitochondria; mf - myelin figure; mv - microvilli; $\mathrm{n}$ - nucleus; RER - rough endoplasmic reticulum.

lagen fibres enter the basement membrane about the muscle attachments. These muscle attachments were observed in the ventroanterior part of the secretory epithelium.

Glycogen particles are rare and present only in the basal parts of the cells. Endoplasmic reticulum (with or without attached ribosomes) is rare, too, and is present in the apical parts of some secretory cells.

Secretory vacuoles are present especially in the apical parts of cells. The genesis of secretory vacuoles (Figs 5, 20) differs from that in soldiers. Electron lucent gaps appear within the dense granules ( 1 to $2 \mu \mathrm{m}$ in diameter) and increase their extent, and the vacuole becomes lucent. During this process small lipid droplets appear within the lucent gaps (Fig. 20). The electron lucent vacuoles frequently fuse with the apical membrane; fusing of vacuoles in other stages of development was observed, too, but infrequently. Most secretory products within the cells are in the form of electron dense granules with or without small lucent gaps. Sexual differences in the frontal gland development were not observed.

\section{Nymph-soldier intercastes}

Cuticular intima covers the whole head part of the gland (Fig. 21), but is lacking completely in the metathorax (Fig. 22). The intima reveals some similarities with that of imagoes. The epicuticle is comprised of the same layers, but is only about $60 \mathrm{~nm}$ thick. Epicuticular filaments are less numerous so their layer is less electron dense then in imagoes (compare Figs 21 and 18) and only from 100 to $400 \mathrm{~nm}$ thick. The basal layer of the cuticle as present in imagoes is lacking in intercastes.

Endoplasmic reticulum occurs in much higher amounts (Fig. 21) than in soldiers or imagoes. Various stages of secretory vacuoles were observed: electron dense vesicles, partially decomposed dense vesicles (Fig. 22), and electron lucent vacuoles including lipids or glycogen or both (Fig. 23) (for schematic drawing see Fig. 5). Vacuoles with dense flocculent coagulations and electron lucent vacuoles were not observed in intercastes. Lipid droplets are often present in the secretory cells. Lipid droplets are locally present in the intercellular spaces (Fig. 24). 
TABLE 2. Total amount of E-1-nitropentadecene in representatives of Prorhinotermes simplex and P. inopinatus.

\begin{tabular}{lc}
\hline & $\begin{array}{c}\text { Quantity of } E \text {-1-nitropentadecene } \\
\text { per individual in } \mu \mathrm{g}\end{array}$ \\
\hline P. simplex presoldier & 0 \\
P. simplex soldier & 27.99 \\
P. simplex female imago & 4.72 \\
$P$. simplex male imago & 5.69 \\
P. simplex intercaste & 0 \\
P. inopinatus soldier & 31.16 \\
\hline
\end{tabular}

\section{Quantity of E-1-nitropentadecene}

The results are summarized in Table 2. The most E-1nitropentadecene was found in soldiers of both species ( $P$. simplex and $P$. inopinatus). The frontal glands of imagoes of $P$. simplex contained moderate quantities of $E-1$ nitropentadecene, whereas it is lacking in presoldiers and intercastes.

\section{DISCUSSION}

\section{Comparison among castes}

At the cellular level, the frontal glands possess only a few common characters among the particular castes. Intercellular junctions are always formed by a desmosome followed by a septate junction. Large amount of microtubules attached to both the desmosomes and basally located hemidesmosomes represent another common feature. Secretory cells form a sac functioning as a reservoir with significant volume changes, and the many microtubules may be correlated with changes in cell shape. The basement membrane in the cephalic part of the frontal gland often contains a considerable amount of collagen fibres. The presence of these fibres seems to be associated with the muscle attachments occurring in the anteroventral parts of the secretory epithelium. The collagen fibres probably strengthen the basement membrane when the muscle causes the reservoir to discharge.

Apart from differences in size and shape of glands and secretory cells, many differences in cell structure appear in soldiers and imagoes. The luminal side of the membrane is formed by long dense microvilli in imagoes, but by irregular projections in soldiers. The basal part forms numerous deep invaginations in imagoes, but the extent of the invaginations is limited in soldiers. Endoplasmic reticulum was observed in the apical parts of secretory cells of imagoes, but it is lacking in soldiers. Although E-1-nitropentadecene is the major component of the secretions in soldiers and imagoes (see below), unexpected differences appear in the development of secretory vacuoles. The initial (electron dense granules) and the terminal stages (electron lucent vacuoles) are similar in both castes, whereas the intermediate stages differ strongly.

Electron dense granules were found in all castes (only rarely in presoldiers); they probably originate from the transformation of large mitochondria. We did not observe this process in the frontal gland, but it was recorded in the labial gland ducts of $P$. simplex (see Šobotník \& Weyda, 2003), in the osmeterium of larvae of Papilio aegeus
Donovan, 1805 (Lepidoptera: Papilionidae) (see Crossley $\&$ Waterhouse, 1969), and in an aggregate part of the silk glands of Araneus diadematus Clerck, 1757 (Arachnida: Araneae: Araneidae) (see Kovoor \& Zylberberg, 1979). Another unexpected fact is that secretory vacuoles are accumulated within the cells at a caste specific stage (initial stages of secretory granule development in imagoes, medial stages in soldiers). In soldiers, certain phases of the development of secretory products (typically stage 3 ) are accompanied by decomposition of glycogen rosettes. Important differences among castes exist in the shape of nuclei, which are always irregular in presoldiers and imagoes but regular and oval in soldiers.

The general structure of the frontal gland appears in presoldiers; the secretory activity does not. It seems that the frontal gland cells in presoldiers produce only the cuticle; secretory vacuoles also appear but are very rare. None of the two cuticles present in some presoldiers appears in soldiers. Epicuticle as observed in some presoldiers (Fig. 6) might be dissolved (but this is highly unlikely) or modified into the structure observed in all soldiers. Therefore we expect that both cuticles are shed during moulting!

\section{Gland in intercastes}

Curious differences between the gland structure in the head and in the metathorax were observed in intercastes. Characteristics common to both intercastes and soldiers occur throughout the entire gland. The sequence of formation of secretory products is similar, but stops in the stage of lipid droplets, and dense flocculent coagulations were not observed. Another common feature is the presence of a large amount of glycogen which frequently envelopes the secretory vacuoles.

Characteristics common to both imagoes and intercastes occur predominantly in the head, e.g., the structure of the cuticle, the presence of dense microvilli, and welldeveloped basal invaginations. Microvilli are present throughout the entire gland; they are longer and dense in the head, but in the metathorax they are shorter and spaced. The similarity between the head part of the frontal gland in intercastes and in imagoes is probably caused by the nymphal origin of intercastes, so many mechanisms unique to imagoes might already have started in nymphs. Interesting differences between intercastes and all other castes exist in the size of mitochondria: these are only about half the size in intercastes.

\section{Comparison with other observations}

The cuticle of soldiers was homologised with outer epicuticle (Quennedey, 1984), but it is without any doubt of endocuticular origin in our samples. The transformation of a normal cuticle into the diffuse layer takes place in the gland near the fontanelle. The frontal gland intima formed by endocuticle is a unique feature of $P$. simplex soldiers. In soldiers of all other investigated species, intima is formed either by epicuticle only or by epicuticle and endocuticle (Deligne et al., 1981; Quennedey, 1984; Costa-Leonardo, 1992). Surprising ambiguity occurs in Coptotermes sp. (Isoptera: Rhinotermitidae) soldiers, 
where the endocuticle was found (Deligne et al., 1981) and was not found (Quennedey, 1984) to form a part of the intima.

The cuticle in imagoes differs from that of soldiers but consists of the same layers as described in frontal glands of soldiers of some other species (Quennedey, 1984). The basal layer is similar to a so-called "inner layer" in soldiers of Reticulitermes santonensis (de Feytaud, 1928) (see Quennedey, 1984; p. 171, Fig 5.8.c) or to mesocuticle in soldiers of Cubitermes fungifaber (Sjöstedt, 1900) (Isoptera: Termitidae) (see Quennedey, 1984; p. 185, Fig 5.13.e).

Our observation of the soldier frontal gland differs dramatically from those made by Quennedey (1984). We may classify the differences into three categories. (i) Organelles observed by Quennedey but not in our samples. These are extensive smooth endoplasmic reticulum and Golgi apparatuses. (ii) Structures frequent in our samples but disregarded by Quennedey. These are microtubules fastened to desmosomes, irregular projections of the apical plasma membrane, occasional basal invaginations, numerous glycogen particles, and other details. (iii) Differences in size. Quennedey mentions nuclei between 3 and $4 \mu \mathrm{m}$, but the nuclei are much larger in our samples (about $6 \mu \mathrm{m}$ ). Quennedey states a size of mitochondria about $3 \mu \mathrm{m}$ while they are usually about $500 \mathrm{~nm}$ and maximally about $2 \mu \mathrm{m}$ in our samples. Such differences are hard to explain. The visual appearance of the secretory cells is similar (Quennedey, 1984; p. 172, Fig. 5.9.a), but his description differs considerably from our observations. The differences in the structure of frontal glands among the studied species are striking; the glands may differ in presence or absence of many organelles and cellular structures (see Deligne et al., 1981; Quennedey, 1984). Therefore, species or even populations may differ to some extent as well and this may be the case with $P$. simplex. The different results may be caused by different methods of fixation, too. Unfortunately, neither the origin of studied animals nor the methods applied are explained by Quennedey (1984).

\section{Production of secretion}

As the common secretory organelles (endoplasmic reticulum, Golgi apparatus) are rare or lacking in P. simplex, the whole process of formation of secretory products probably takes place within secretory vacuoles. This may explain the complicated but stable way of production of the secretion. The major component of secretion, $E-1$ nitropentadecene, is probably synthesised from lipids, which appear inside the secretory vacuoles in stage 3 and following phases of their development.

Several observations similar to certain steps of secretory vacuoles development in $P$. simplex have been published, e.g., secretory vacuoles associated with mitochondria in soldiers of Psammotermes hybostoma Desneux, 1902 (Isoptera: Rhinotermitidae) (see Quennedey, 1984), or abundance of glycogen granules often associated with large myeloid vesicles of secretion in soldiers of Schedorhinotermes putorius (Sjöstedt, 1911) (see Quennedey, 1984).
A striking disproportion exists between the considerable amount of nitropentadecene in the reservoir and the low abundance of secretory vacuoles in the gland cells. It is likely that the definitive toxic secretion is stored predominantly inside the reservoir whose cuticle together with the secretory epithelium properties prevents autotoxication. Therefore, the secretory cells probably contain only a low amount of nontoxic precursors in castespecific stages.

The ascertained quantity of $E$-1-nitropentadecene corresponds to structural features of the glands in particular castes. Secretory vacuoles are very rare in presoldiers and nitropentadecene is lacking there. The most of nitropentadecene was found in soldiers, which are equipped with a very large gland, but the secretory cells are probably only moderately active as the amount of mitochondria is relatively low. The amount of nitropentadecene in imagoes is relatively high, about one fifth of the amount in soldiers. This fact may be explained by higher activity of secretory cells in imagoes, which is evidenced by a considerably higher number of mitochondria and well-developed tracheization. Vacuoles within the secretory cells of intercastes undergo typical development that stops at the stage of lipid droplets, and lipids accumulate within the cells. The sample contains no nitropentadecene.

\section{Quantity of defensive products}

The detected quantities of $E$-1-nitropentadecene in soldiers and imagoes of $P$. simplex highly exceed (56 to 1400 times) quantities of geranyl linalool, the major component of frontal gland secretion in Reticulitermes spp. soldiers (Clément et al., 1988). This can be explained by the larger size of the frontal gland reservoir in $P$. simplex soldiers (pers. observ.) and by the supposed high secretory activity of frontal gland cells in $P$. simplex imagoes as evidenced by the large number of mitochondria and the large extent of basal invaginations. The average amount of nitropentadecene in $P$. simplex soldiers $(27.99 \mathrm{mg}$ per individual) represents $1 / 120$ of the average weight of soldier (3.3 mg, unpublished data provided by Kuldová \& Hrdý). This seems to be a reliable quantity according to the enormous volume of the frontal gland reservoir.

ACKNOWLEDGEMENTS. We would like to thank Yves Roisin (Université Libre de Bruxelles, Belgium) for determination of Prorhinotermes inopinatus. We are grateful to Pavel Štys for critical reading of the manuscript and valuable comments. We thank Jitka Pflegerová (Institute of Entomology, Czech Academy of Sciences, Czech Republic) and Jana Nebesářová and the staff of Laboratory of Electron Microscopy (Institute of Parasitology, Czech Academy of Sciences, Czech Republic) for their help in electron microscopical investigations. We thank Martina Janoušková (Institute of Botany, Praha) for English review. We also thank Jelena Kuldová and Ivan Hrdý for providing their unpublished data. We are grateful to Jan Hubert for his help with light microscopy. The material of Prorhinotermes inopinatus was obtained with help of the projects funded by U.S. National Science Foundation (DEB-94-07297, DEB-9628840 and DEB-97-07928). This research was supported by the grant of Czech Academy of Sciences (project No. S 4055104). J. Šobotník, R. Hanus, P. Kyjaková, and J. Doubský thank to Z4 055905 project realized in IOCB, Prague. 


\section{REFERENCES}

Bordereau C., Robert A., Van Tuyen V. \& Peppuy A. 1997: Suicidal defensive behaviour by frontal gland dehiscence in Globitermes sulphureus Haviland soldiers (Isoptera). Ins. Soc. 44: 289-297.

Chunh C.H., Goh S.H. \& Tho Y.P. 1990: Chemical defense secretions of some species of Malaysian Rhinotermitidae (Isoptera: Rhinotermitidae). J. Chem. Ecol. 16: 685-692.

Clément J.-L., Lemaire M., Nagnan P., Escoubas P., Bagneres A.G. \& Joulie C. 1988: Chemical ecology of European termites of the genus Reticulitermes. Allomones, pheromones and kairomones. Sociobiology 14: 165-173.

Costa-Leonardo A.M. 1992: The secretory epithelium of the frontal gland in Velocitermes sp. soldiers (Isoptera: Termitidae). Naturalia 17: 99-109.

Costa-Leonardo A.M. 1998: The frontal weapon of the termite soldier Serritermes serrifer (Isoptera: Serritermitidae). Ciencia e Cultura 50: 65-67.

Costa-Leonardo A.M. \& Kitayama K. 1991: Frontal gland dehiscence in the Brazilian termite Serritermes serrifer (Isoptera: Serritermitidae). Sociobiology 19: 333-338.

Crossley A.C. \& Waterhouse D.F. 1969: The ultrastrucure of the osmeterium and the nature of its secretion in Papilio larvae (Lepidoptera). Tissue \& Cell 1: 525-554.

Deligne J., Quennedey A. \& Blum M.S. 1981: The enemies and defense mechanisms of termites. In: Hermann H.R. (ed.): Social Insects, Vol. II. Academic press, New York, pp. 1-76.

Kovoor J. \& Zylberberg L. 1979: Ultrastructure du canal des glandes agrégées et flagelliformes d'Araneus diadematus Clerck (Araneae: Araneidae). Zoomorphologie 92: 217-239.

Kuldová J., Hrdý I. \& Svatoš A. 1999: Defense secretion of Prorhinotermes simplex: Toxicity to insecticide susceptible and resistant house fly. J. Chem. Ecol. 25: 657-662.

Lefeuve P. \& Bordereau C. 1984: Soldier formation regulated by a primer pheromone from the soldier frontal gland in a higher termite Nasutitermes lujae. Proc. Nat. Acad. Sci. USA - Biol. Sci. 81: 7665-7668.

Lelis A.T. \& Everaerts C. 1993: Effects of juvenile-hormone analogs upon soldier differentiation in the termite Reticulitermes santonensis (Rhinotermitidae: Heterotermitinae). $J$. Morphol. 217: 239-261.

Myles T.G. \& Chang F. 1984: The caste systems and caste mechanisms of Neotermes connexus (Isoptera: Kalotermitidae). Sociobiology 9: 163-321.
Noirot C. 1969: Glands and secretions. In: Krishna K. \& Weesner F.M. (eds): Biology of Termites, Vol. I. Academic press, New York, pp. 89-123.

Notrot C. \& QuenNedey A. 1974: Fine structure of insect epidermal glands. Annu. Rev. Entomol. 19: 61-80.

Prestwich G.D. 1984: Defence mechanisms of termites. Annu. Rev. Entomol. 29: 201-232.

QuENNEDEY A. 1984: Morphology and ultrastructure of termite defense glands. In: Hermann H.R. (ed.): Defensive Mechanisms in Social Insects. Praeger, New York, pp. 151-200.

Renoux J. 1976: Le polymorfisme de Schedorhinotermes lamanianus (Sjöstedt) (Isoptera: Rhinotermitidae). Essai d'interpretation. Ins. Soc. 22: 279-494.

Roisin Y., Everaerts C., Pasteels J.M. \& Bonnard O. 1990: Caste-dependent reactions to soldier defensive secretion and chiral alarm/recruitment pheromone in Nasutitermes princeps. J. Chem. Ecol. 16: 2865-2875.

Spanton S.G. \& Prestwich G.D. 1981: Chemical self-defence by termite workers: Prevention of autotoxication in two rhinotermitids. Science 214: 1363-1365.

Springhetti A. \& Rossi R. 1983: A biometric study of the morphogenesis of soldiers and intercastes of Kalotermes flavicollis Fabr. (Isoptera). Monitore Zool. Ital. 17: 143-151.

Su N.-Y. \& Schefrrahn R.H. 1990: Potential of insect growth regulators as termiticides: a review. Sociobiology 17: 313-328.

Šobotní J. \& Hubert J. 2003: The morphology of the exocrine glands of Prorhinotermes simplex (Isoptera: Rhinotermitidae) and their ontogenetical aspects. Acta Soc. Zool. Bohem. 67: 83-98.

Šовотлі́ J. \& WeYda F. 2003: Ultrastructural ontogeny of the labial gland apparatus in termite Prorhinotermes simplex (Isoptera: Rhinotermitidae). Arthropod Struct. Dev. 31: 255-270.

VRKOČ J. \& UBIK K. 1974: 1-nitro-trans-1-pentadecene as the defensive compound of termites. Tetrahed. Lett. 15: $1463-1464$.

Wimmer Z., Rejzek M., Zarevúcka M., Kuldová J., Hrdý I., NĚMEC V. \& RoMAŇUK M. 1997: A series of bicyclic insect juvenile hormone analogs of Czech origin: twenty years of development. J. Chem. Ecol. 23: 605-628.

Received May 28, 2003; revised September 23, 2003; accepted November 3, 2003 